\title{
Cottonwood in the Missouri Breaks National Monument
}

\section{Background}

Concerns about cottonwood along the Wild and Scenic reach of the upper Missouri River include declining forests of sparse old trees with little recruitment of new individuals (fig. 1), impacts of cattle grazing and recreational use, and effects of flow alterations from operation of upstream dams and changes in tributary inflows.

The Missouri Breaks National Monument contains a unique portion of the Missouri River that is largely unchanged in overall character from pre-development conditions (fig. 2). National interest in this reach and concomitant recreational use are

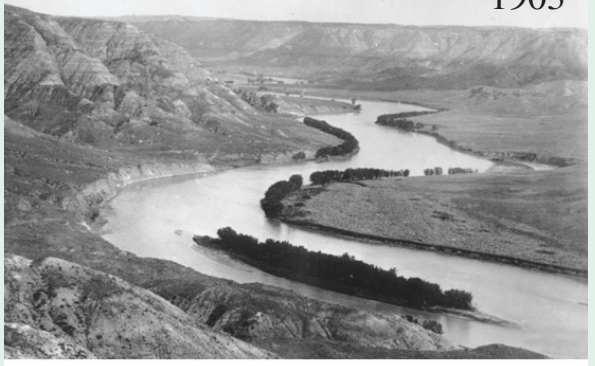

2000

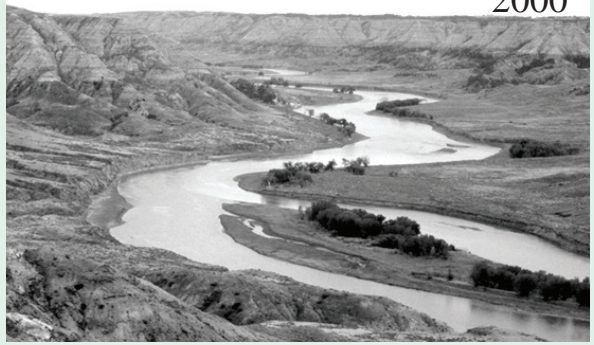

Figure 2. Changes in the vicinity of Iron City Island. In the downstream, constrained section with little channel change (top of photo) trees have been lost from high alluvial surfaces. Regeneration has occurred in the less constrained areas associated with filling of a back channel (center of photo) and island movement (bottom of photo). 1903 photo by T.W. Stanton, U.S. Geological Survey Photo Archives, Denver, Colorado; 2000 photo by M.F. Merigliano.

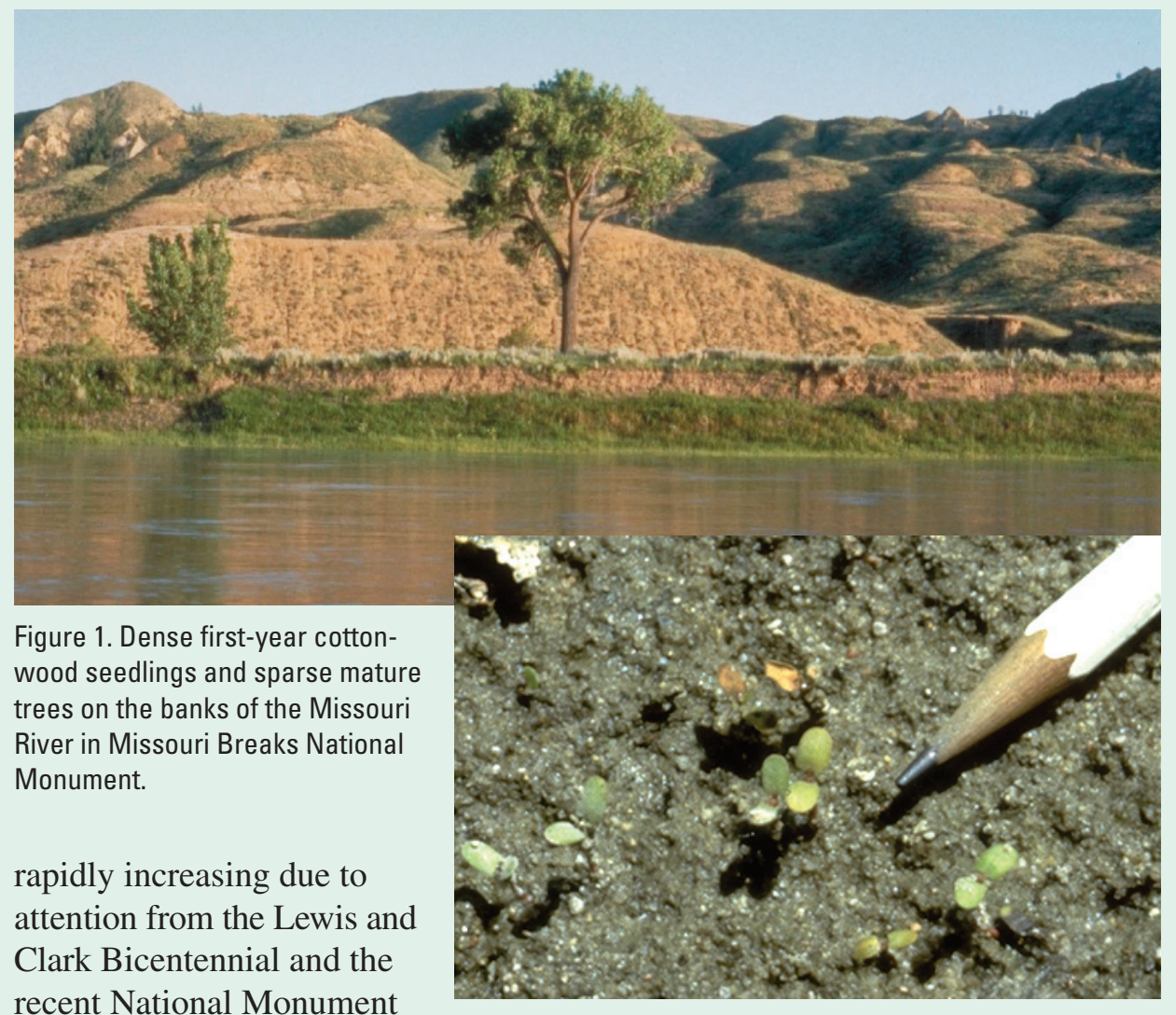

recent National Monument designation. The reach presents a rare, undeveloped contrast to other large sections of the Missouri River that have been dramatically altered by agricultural conversion, urban development, channelization, and impoundment. The U.S. Geological Survey (USGS) and Bureau of Land Management (BLM) have been studying the factors controlling cottonwood along the Wild and Scenic reach in cooperation with the Fish and Wildlife Service, the Bureau of Reclamation, the hydropower company Pennsylvania Power and Light - Montana, and the University of Montana. The two primary studies are (1) a retrospective analysis of existing trees using tree coring and historical records, and (2) an ongoing, longterm monitoring of seedling establishment, growth, and mortality at permanent plots.

\section{Cottonwood Ecology}

Riparian cottonwoods provide important habitat and aesthetic values in the western U.S. where surrounding uplands are often too dry to support trees. The plains cottonwood (Populus deltoides subsp. monilifera) occurring along the Wild and Scenic reach of the Missouri River has a lifespan of roughly 150 years.

The conditions associated with successful establishment of cottonwood are well known. An abundant crop of wind- and water-dispersed seeds is released in early summer. The seeds can germinate immediately, but lose germinability under field conditions within a few weeks. Because they are small-seeded and intolerant of shade, cottonwoods are unlikely to establish from seed under an existing stand of trees. Freshly 

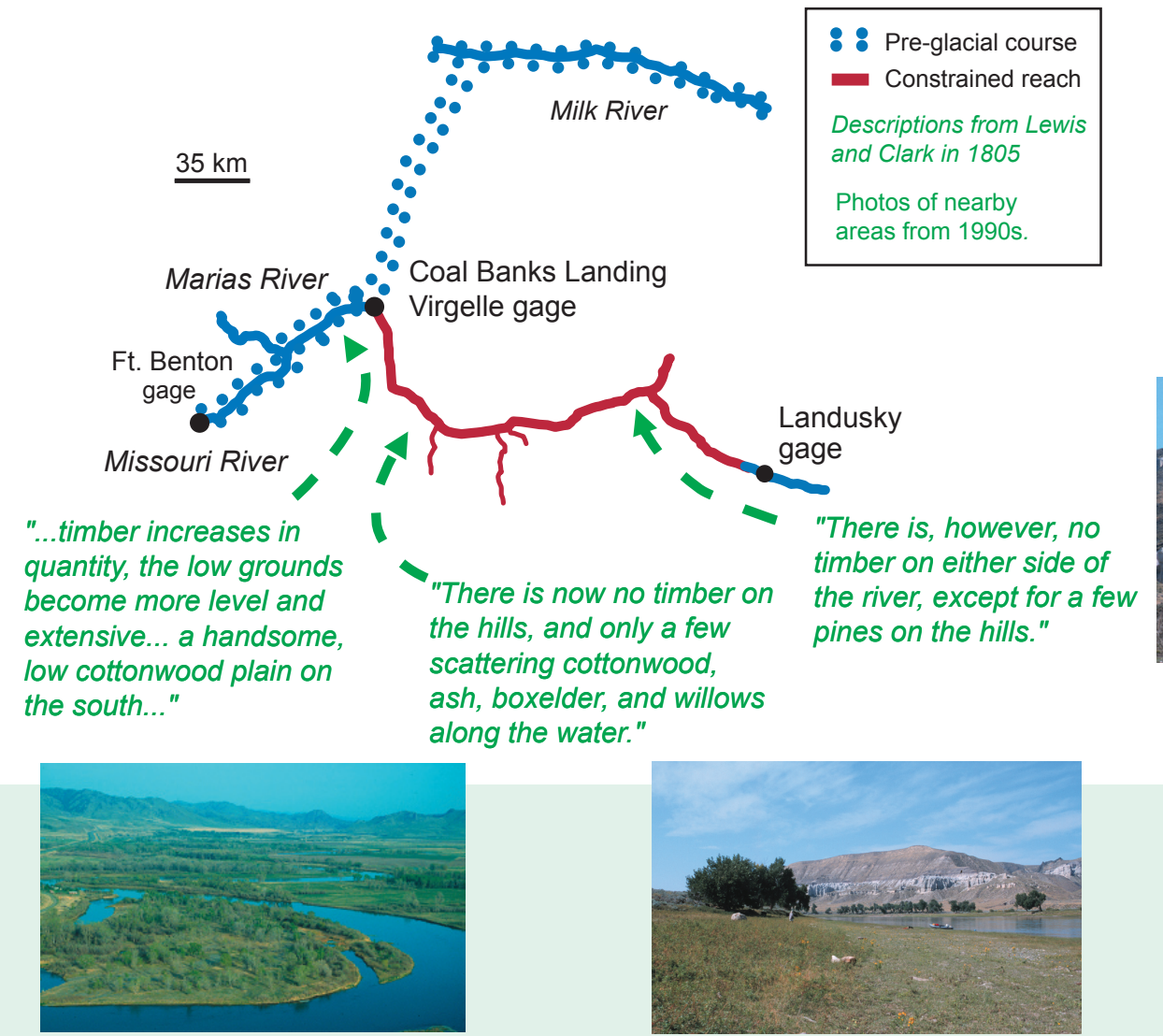

deposited or disturbed alluvium typically provides ideal substrate for germination and establishment, however young seedlings are also sensitive to mortality from flooding, burial, and scouring.

The conditions required for cottonwood recruitment can be summarized as bare, moist sites that are relatively safe from subsequent disturbance. These are restrictive requirements and are met most frequently and extensively by flow-induced channel change. Fluvial geomorphic processes like channel narrowing, meandering, as well as vertical accretion of alluvial surfaces by flood deposition produce the bare, moist substrates suitable for cottonwood regeneration and result in distinctive spatial and temporal patterns of cottonwood forest.

\section{Missouri Breaks Cottonwood}

The relative scarcity of cottonwood in the Missouri Breaks is partially explained by geologic setting. Before the Pleistocene, the Missouri River diverged from its modern course near Coal Banks Landing, flowing north
Figure 3. Constrained reach of Missouri River, Montana, and the pre-glacial course redrawn from Lemke and others (1965) and Scott and others (1996). Quoted descriptions of riparian vegetation in 1805 are from Lewis and Clark journals (Coues, 1893). Photographs from nearby areas in the 1990s show little change in basic character of the forest.

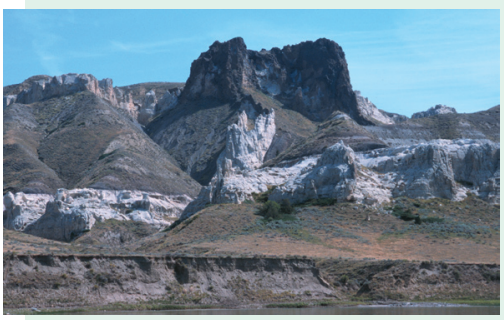

Wild and Scenic reach occur in less constrained areas such as back channels and islands (fig. 4) and tributary junctions such as the mouth of the Judith River.

The Missouri River in Montana has a snowmelt-dominated hydrograph, with peak flows typically occurring in late May or early June and low flows occurring in fall and winter. Infrequently large floods occur when upslope orographic precipitation in May and June combines with snowmelt runoff. Stages produced by winter ice jams are frequently higher than

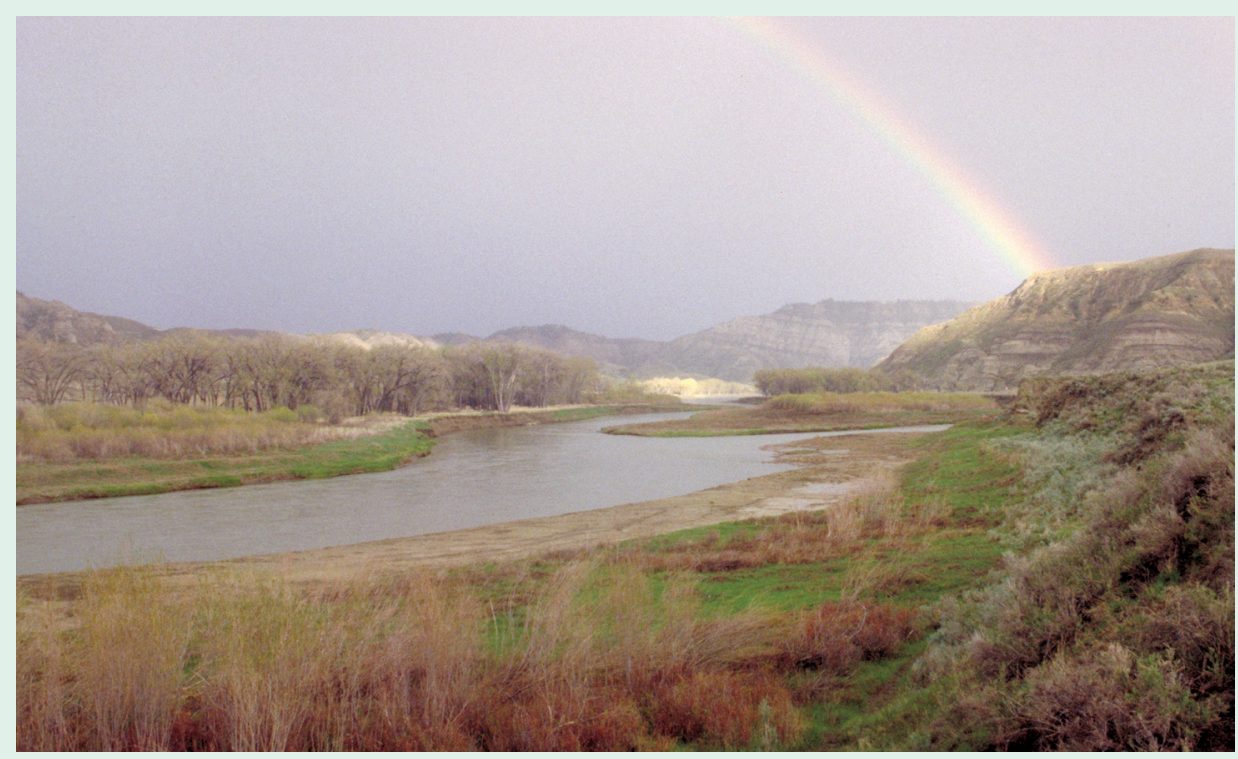

Figure 4. Mature stand of cottonwood on Cow Island viewed from side channel of Missouri River. 
stages associated with the highest discharge of the year. Recurrently, but infrequently, extreme ice stages are produced by mechanical ice breakups when rapid warming by downslope winds occurs in winter. Since the mid-1950s, flows within the Wild and Scenic reach of the Missouri have been influenced by operation of two upstream Bureau of Reclamation storage reservoirs and several smaller hydropower dams.

Historical accounts, including Lewis and Clark journals, suggest that cottonwood stands in the Missouri Breaks were also sparse and discontinuous prior to European settlement of the region (fig. 3 , Coues, 1893). The majority of existing trees within this reach established as seedlings in association with infrequent, high-magnitude floods.

In a retrospective analysis linking historical stream flows to establishment years of excavated cottonwood stems, we concluded that because of limited channel movement, only infrequent, large flows could create the physical site conditions required for successful tree establishment (Scott and others, 1997). However, that analysis provided only indirect evidence about the factors controlling cottonwood recruitment and could not quantify the relative importance of flow modification from upstream dams and cattle grazing which has occurred over the last 100 years (figs. 5 and 6).

\section{Cottonwood Monitoring}

USGS began monitoring a set of four livestock grazing exclosures maintained by BLM in 1996. For each exclosure, there is a paired, unfenced site. Monitoring of establishment, growth, and mortality is based on an annual census of cottonwoods by agesize class in plots at 1-m intervals along multiple transects at each of the eight sites. Physical measurements include surveys of elevation for channel change and water stage recorders at each site to relate streamflow at an upstream, long-term gage and water surface elevations at the sites.

Results to date confirm the role of cottonwood as a pioneer, disturbance-dependent species that best establishes from seed on surfaces that are bare and moist during a relatively brief period following seed dispersal (Auble and Scott, 1998; Bovee and Scott, 2002; Scott and Auble, 2002; Scott and others, 2003). Each year, new seedlings are positioned in a zone wetted by summer water on the best locations. Recruitment of these seedlings to trees depends on the site being relatively safe from future disturbance and the vast majority of these seedlings do not survive.
Fig. 5. Cattle grazing.
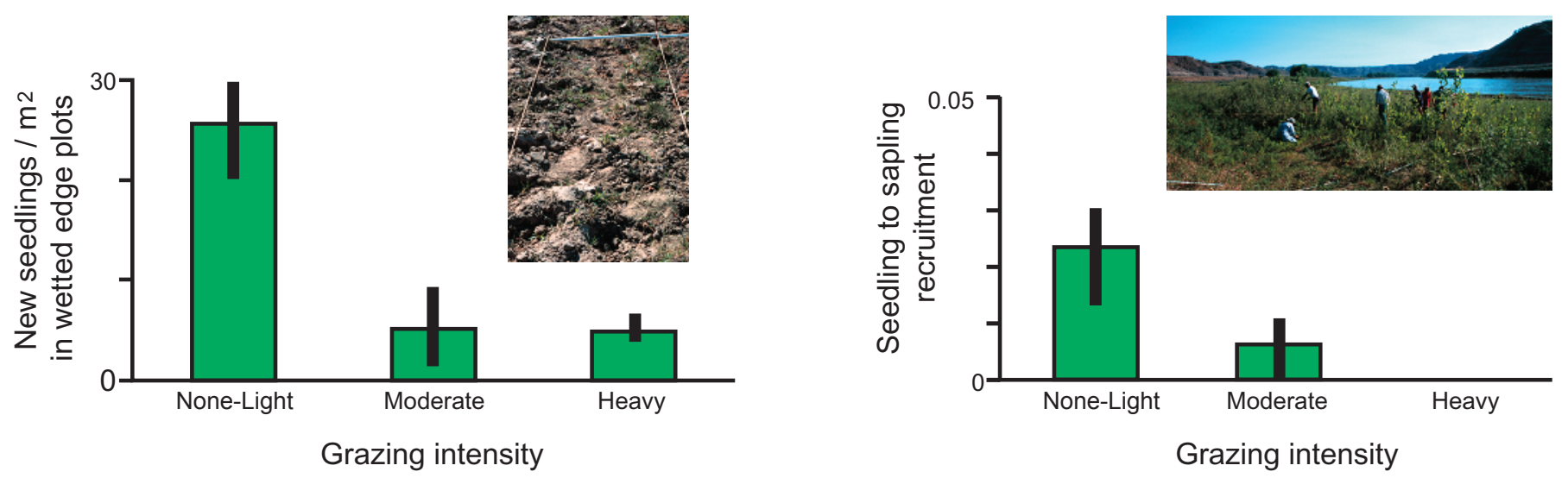

Figure 7. Annual recruitment from seedling to sapling size class and annual establishment of new seedlings as functions of grazing intensity. Redrawn from Auble and others (2001). 


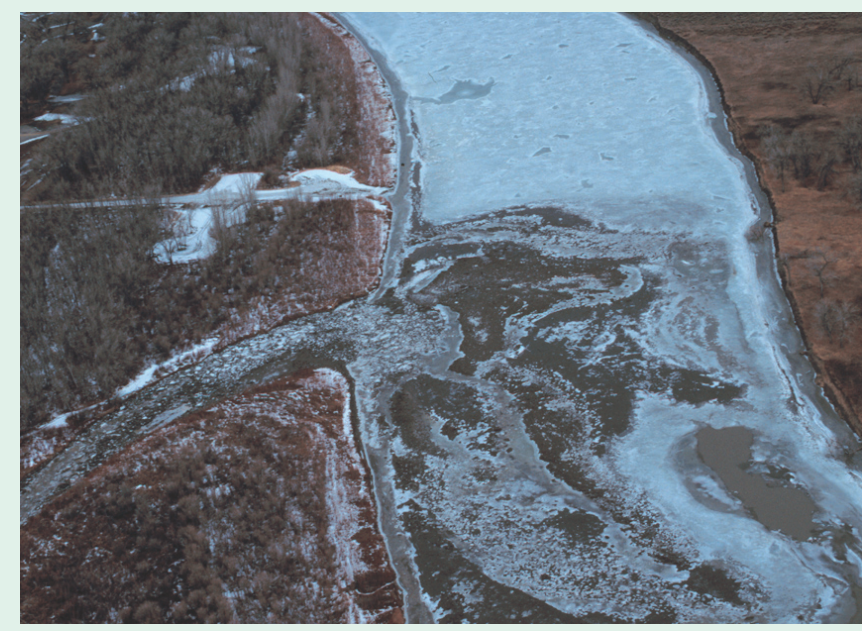

Figure 8. Ice on the Missouri River. Note flow from partially melted tributary entering still-frozen mainstem.

and mortality rates as functions of both grazing and stream flow. Since 1996, we have observed seedling establishment, mortality, recruitment to sapling and pole stages, and sediment accretion and erosion through sequences of normal and dry years. To some extent, the positive recruitment response from a sequence of normal to dry years mirrors the response expected from a sequence of wet to normal years. However, survival through the next episodic ice scour (fig. 8) or flood is uncertain because along the laterally constrained Wild and Scenic reach of the upper Missouri River in the Missouri Breaks, most trees were established by flood flows that position them as seedlings high enough on the banks to survive mortality from subsequent floods and episodic ice scour (fig. 9).

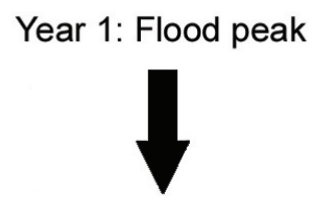

Future Normal Years: Smaller peaks/lce drives:
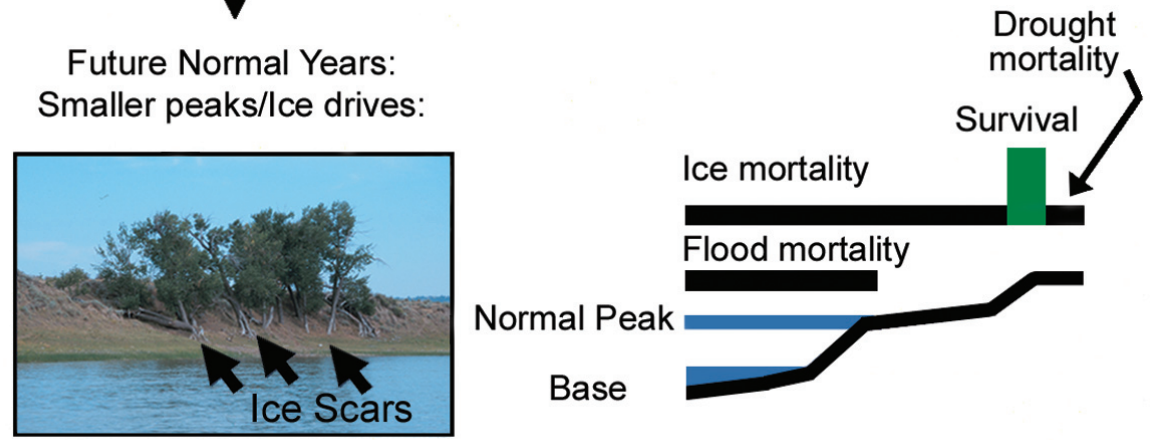

Figure 9. Diagram of flood-dependent recruitment of cottonwood along constrained, ice-prone reach of the upper Missouri River. Major ice events are less frequent and trees at the higher elevations tend to grow large enough to withstand infrequent, major ice events.
Coues, E., ed., 1893, The history of the Lewis and Clark Expedition: Volume I of IV, Francis P. Harper, New York, USA, Unabridged republication by Dover Publications, Inc., New York, NY, USA.

Lemke, R.W., Laird, W.M., Tipton, M.J., and Lindvall, R.M., 1965, Quaternary geology of the northern Great Plains, in Wright, Jr., H.E., and Frye, J.C., eds., The quaternary of the United States: Princeton University Press, Princeton, NJ, US, p. 15-27.

Scott, M.L., and Auble, G.T., 2002, Conservation and restoration of semi-arid riparian forests: a case study from the Upper Missouri River, Montana, USA, in Middleton, B., ed., Flood pulsing and wetland restoration in North America: John Wiley and Sons, Inc., p. 145-190.

Scott, M.L., Auble, G.T., and Friedman, J.M., 1997, Flood dependency of cottonwood establishment along the Missouri River, Montana, USA: Ecological Applications, v. 7, p. 677-690.

Scott, M.L., Friedman, J.M., and Auble, G.T., 1996, Fluvial process and the establishment of bottomland trees: Geomorphology, v. 14, p. 327-339.

Scott, M.L., Skagen, S.K., and Merigliano, M.F., 2003, Relating geomorphic change and grazing to avian communities in riparian forests: Conservation Biology, v. 7, p. 284-296.

Wayne, W.J., Aber, J.S., Agard, S.S., Bergantino, R.N., Bluemle, J.P., Coates, D.A., Cooley, M.E., Madole, R.F., Martin, J.E., Mears, Jr., B., Morrison, R.B., and Sutherland, W.M., 1991, Quaternary geology of the northern Great Plains, in Morrison, R.B., ed.: Geology of North America, Volume K2, The Geological Society of America, Boulder, CO, USA, p. 441-476.

\section{Investigators}

Gregor Auble and Michael Scott, U.S. Geological Survey

Joseph Frazier and Chad Krause, Bureau of Land Management

Michael Merigliano, University of Montana 